\title{
A Geo-physical background of Ravi River Basin in Himachal Pradesh
}

\author{
Sharma Nikesh \\ Assistant Professor of Geography, \\ Government College Dharamshala, \\ Himachal Pradesh, India.
}

\begin{abstract}
The Ravi River is one of the main River of Indus River systems and it is originates at an elevation of 4229 meters above mean sea level from Bara Bangal the most interior part of Kangra District. The River flows in a North-West direction for most of its course. There are 34293 streams of different orders are found in this basin in Himachal Pradesh. This basin is mostly dendritic pattern but in some places the herringbone drainage patterns are also found. The Dhauladhar and Pirpanjal are two main mountain ranges in this basin. Physiographically, the entire basin is mountainous with an altitude ranging from 559 to 5563 meters above the mean sea level. It lies between $32^{\circ} 11^{\prime} 30^{\prime \prime}$ and $33^{\circ} 01^{\prime} 5^{\prime \prime}$ north latitudes and $75^{\circ} 48^{\prime}$ and $77^{\circ} 45^{\prime}$ east longitudes. The Chamba valley is found in lower altitude, while Bara Bangal valley is lies below the source area of this River. In this basin various types of soils are found like typic- udorthents, dystric-eutrochrepts etc. Due to altitudes variation, a variety of climate is found from the semi-tropical to the semi-arctic. In this basin the Saluni formation rocks are mostly concentrated in large portion of entire basin.
\end{abstract}

Keywords: Drainage, Dendritic, Tropical, Arctic, Altitude.

\section{INTRODUCTION}

Physiographically, the entire basin is mountainous with an altitude ranging from 559 metres to 5563 metres above the mean sea level. The habitation is found only up to 3,000 metres. The Ravi River basin is a part of the Northern Himachal Himalaya. It lies between $32^{0} 11^{\prime} 30^{\prime \prime}$ and $33^{\circ} 01^{\prime} 5^{\prime \prime}$ north latitudes and $75^{\circ} 48^{\prime}$ and $77^{\circ} 45^{\prime}$ east longitudes (compile from toposheets of Chamba and Kangra). This basin is bounded on the north and west by Jammu \& Kashmir state, on the south-west by Punjab state, on the south and south-east by Kangra district whereas Lahul \& Spiti district encloses it from east (Census report 2001).

The Ravi River originates from Bara Banghal at an elevation of 4229 meters above mean sea level, a propos 150 Kilometers North-East of historical Chamba town. The Ravi flows in steep gradient with series of loops and bends. In between, main tributaries like Kalihan, Budhil, Tundah, Seul and Baira contribute lot of run-off to the Ravi. Bara Banghal encompass of snow covered peaks at heights ranging from 3050 meters to 5800 meters above mean sea level. The basin represents some remarkable physical features. The River flows in a North-West direction for most of its course, rises in Baira-Balsio and continues through Traila and Chhanota to Ulansa, where it is joined by two of its major tributaries in the head reaches Viz. Budhil and Tundah. Beyond this, up to Chhatrari, River flows through a narrow gorge where it opens out. After passing through Churi,
Bagga, Mehla, Chamba and Udaipur, the River approaches Rajnagar, and then flows in narrow gorge to Sherpur. The Siul River, the largest tributary, joins the Ravi upstream of Chamera Stage-I Dam. The Sewa River flowing from the north joins the Ravi near Khairi. It then bends to the South-West and striking the terminal spurs of the Dhauladhar range, separates Chamba from Jammu and Kashmir and finally leaves the territory of Himachal Pradesh up stream of Ranjit Sagar Dam (Punjab). Budhil nallah has its origin on the slopes of the mid Himalayas near Kugtipass. At Harsar, it receives on its left bank the small stream from sacred Lake of Mani-Mahesh, situated beneath the peak called the Mani-Mahesh, Kailash at an elevation of 3952 meters. It passes Village Bharmour at $14 \mathrm{Kms}$. downstream and soon afterwards meets the Ravi near Village Kharamukh. Tundah nallah rises at Kalicho top Pass, flows through Tundah valley and joins the Ravi below Kharamukh. The right bank tributaries are bigger and have more discharge as compared to the left bank tributaries except Kalihan, which originates in Dhauladhar range on the left bank and contributes a good discharge. Both Budhil and Tundah are about 54 kilometres long each (Central electricity report, June 2004).

There are total 34293 streams and out of this 27701 streams of first order, 5162 of second order streams, 1094 of third order, 253 of fourth order, 62 of fifth order, 17 of sixth order, 3 of seventh order and 1 of eighth order streams in Ravi River basin in Himachal Pradesh (Figure 1). 


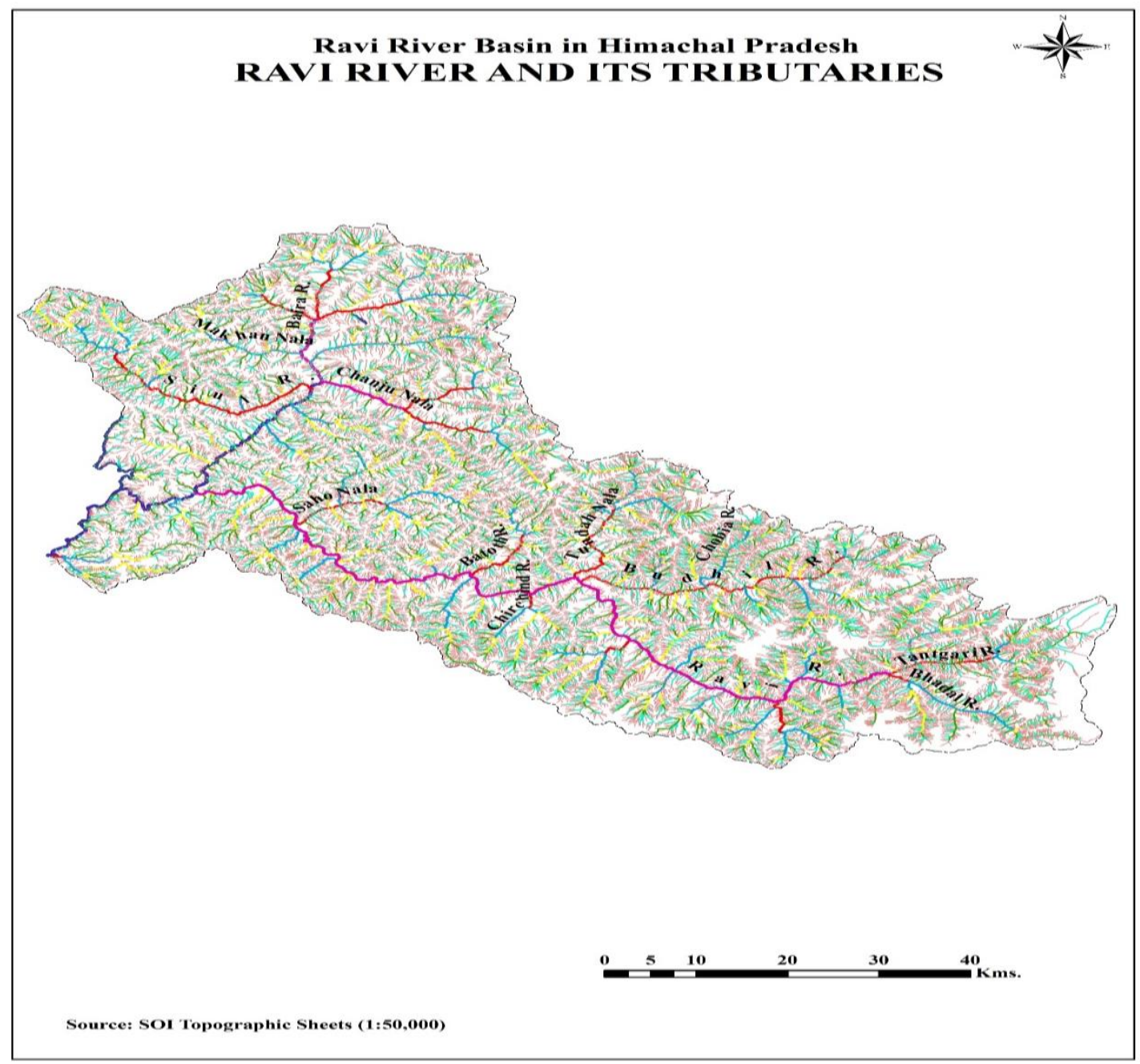

Figure 1

\section{RESEARCH OBJECTIVES}

In this Research Paper the Geo-Physical background aspects of Ravi River Basin area in Himachal Pradesh have been analyzed.

\section{METHODOLOGY}

The Research methodology of this research paper is qualitative as well as quantitative. The data of this research paper are obtained from topographical sheets of Kangra and Chamba Districts of Himachal Pradesh. The other data obtained from Census report 2001, Central electricity report, 2004, Hydro electricity report, 2004 etc.

\section{DATA ANALYSIS/ FINDING 4.1 Drainage Pattern}

The drainage pattern means the form of the drainage systems and the spatial arrangement of streams in a particular locality or region. The location, number and flow directions of different streams of a particular region depends on the nature of slope, structural control, lithological characteristics, tectonic factors, climatic conditions, vegetal characteristics etc. (Singh, Savindra 1997). In this basin the dendritic or tree shaped pattern is mostly common due to mountainous dissected topography. The pattern is called dendritic on the ground that the network of tributaries of various orders and magnitudes of the trunk or master stream resembles the branches and roots and rootlets of a tree. The dendritic pattern is associated with the areas of homogenous lithologies. Though dendritic pattern is independent of structural and lithological controls but almost uniform lithology presents most ideal condition for the development of dendritic drainage pattern. This pattern develops in a variety of structural and lithological environments such as in the mountainous and hilly areas such as Himalayas (Singh, Savindra, 1997). In some areas of this basin the herringbone drainage pattern is also found. Herringbone drainage pattern, also known as Rib pattern is developed in mountainous areas where broad valleys are flanked by parallel ridges having steep hillside slopes. The longitudinal consequent streams, as master streams are developed in the 


\section{Available online at www.ijrat.org}

longitudinal parallel valleys while tributaries, lateral consequent, after originating from the hill slopes of the bordering parallel ridges join the longitudinal consequents almost at right angle. The courses of the tributaries are straightened because of slope factor and little distance between the ridges and the longitudinal consequents occupying the valleys and thus the tributaries are not allowed to adapt sinuous course and join the longitudinal consequents at acute angles (Singh, Savindra, 1997). The study area has dendritic drainage type pattern, but in some part of basin it is also a herringbone pattern appear like in Budhil, Tantgari, Bhadal etc. tributaries of Ravi River. The occurrence of this drainage system indicates homogeneous, uniform soil and rock material.

\subsection{Topography of Ravi River Basin in Himachal Pradesh}

Lying mostly on both sides of the Pirpanjal and touching the Dauladhar on the southern fringe, the Ravi catchment area is rugged and covered with the spurs of the high ranges. The Dhauladhar range separating the basin of the Beas from that of the Ravi, the Pangi or Pirpanjal range dividing the Watershed between the Ravi and Chenab are the two well defined snowy ranges, constituting the main topographical features of the area. The Dhauladhar range running in North-West direction forms the boundary between Mandi and Kullu Districts, at the point where it gives off Bara Banghal branch to join the mid Himalayas. It makes a sudden bend westward and for the first time touches Chamba District, on the southern border. From this point, it continues for about $50 \mathrm{Kms}$. forming the boundaries between Kangra and the Chamba Districts. It begins on the right bank of the Beas and running north to west forming the boundary between Kullu and Mandi. Dhauladhar forms a lofty mountain barrier with peaks from 4,300 meters to 5,200 meters. The passes are from 2,400 meters to 4,600 meters and here some important passes are chauri, Jalsu, Baleni, Indrahar, Tori and Talang pass etc. The lower slopes are covered with forests of oak and pine. The sites are seamed with winter coarses. The lofty peaks rise in stern and rugged grandeur covered by wastes of snow.

The Pirpanjal range known as the Pangi range within the Chamba District after separating Kullu from Lahaul-Spiti, enters Chamba district on the western border of the Bara Banghal and traverses the district from South-East to North-West for more than $100 \mathrm{Kms}$. On the North-Western border, where the Pangi range leaves the territory, it gives off a branch to the South-West called the Daganidhar which forms the boundary between Chamba and Bhadrawah of Jammu and Kashmir. At its western extremity, this branch is connected by a short ridge, in which the Padri and the Chatardhar passes. Topographically, the Dagnidhar and the Chatardhar are different sections of one continuous offshoot, forming with the Pangi Range, the water shed between the Ravi and the Chander-Bhaga (Chenab) (Hydro Electricity Report, 2004). The second one is Pirpanjal and this range (Census report, 2001) divides Chamba from Lahaul and Spiti district in north east direction. In this range covering most of parts of Bharmour and Chaurah tehsils and some parts of Chamba and Holi are also covered in this range (Census Report, 2001). This mountain range separates the Basin of Ravi River and Chenab River and some important passes of this range are Darati, Kalicho, Chobia, Shipting, Duggi, and Chobu etc.

\subsection{Valleys of Ravi River Basin in Himachal Pradesh}

There is Ravi valley or Chamba valley which is located in the lower reach and is not much fertile. The Ravi or Chamba valley, as a whole is adequately open and presents many amusing contrasts. In the lower areas of the valley, vegetation is semi-tropical and at the higher elevation the trees belonging to pinus longifolia, oak and chestnut are found and above, there are birch and juniper. In this valley the villages are diminutive. In the villages up to an altitude of 2,100 meters two crops are sown while in the villages above 2,100 meters only one crop is grown. With the addition at small portion of the lower Ravi valley forms the Bhattiyat and Dalhousie tehsils. It is most populous and fertile valley of the district. Its vegetation is semi-tropical and the bamboo, pipal and the mango flourish luxuriantly in the course of proximity of the fir, the barberry and the oak. Generally, two crops are sown in a year (Census report, 2001).

The Bara Bhangal Valley adjoining to the Kangra Valley and lies between the Dhauladhar and Pirpanjal Ranges. It is partly in Kangra and partly in Chamba district. The Ravi River rises from the slopes of this Valley (Balokhra, J.M, 2000).

\subsection{Micro Sub-Regions of the Basin}

Physiographically, the entire basin is mountainous with an altitude ranging from 559 meters to 6,162 meters above the mean sea level. The habitation is found only up to 3,000 meters. The climate is found varying from semi-tropical to semi-arctic. In lower areas, climatic conditions are similar to those of Kangra district, while in higher altitude the climate is of temperate type. The geological structure is mostly formed by Jutogh group/Vaikrita group and Central gneiss types besides other groups like Granites (unclassified), Blaini/Infra-Krol formations, Shimla group, Panjal traps and Siwalik formations. It has also shale types of rocks, slate, sand stone, lime stone, conglomerates and quartzites. The types of soils found in this region as classified by the N.B.S.S. \& L.U.P. (I.C.A.R.) Nagpur, are Udalfs, Ochrepts, Ochrepts- 


\section{Available online at www.ijrat.org}

Orthents, Ochrepts-Orthents-Ustalfs and Udolls. Forests have great importance in the economy of the Himachal Pradesh as a whole and Ravi basin in particular. In lower areas of the valleys, vegetation is of semi-tropical type and at the higher elevation, the Deodars, Pine/Blue Pine, mixed coniferous and oak forests are found and above these elevation Moist Alpine scrub or meadows are seen. On the basis of physiography, climate, soils, vegetation and geology, this basin is divided into sub-micron regions, the details of which are given below:

\subsubsection{Pirpanjal Range}

This region is situated extending longitudinally from north-west to south-east direction covering the major parts of Chaurah and Brahmaur tehsils and also small areas of Chamba tehsils and Holi sub-tehsil. It makes its boundaries with Jammu \& Kashmir in the north and north-west, with the Ravi Basin in the south, with Kangra district in the south-east and the Chandra valley and Lahul \& Spiti district in the north-east. Physiographically, the region has many hill ranges/Dhars and prominent among them are Pangi Dhar, Drabla Dhar, Deorah Dhar, Dodana Dhar, Sanini Dhar, Manimahesh Dhar etc. The region has an altitude varying between 2,698 metres and 5,857 metres above the mean sea level. The maximum height of 5,857 metres is at Bar Kanda in the northern Bharmour tehsil. Sach pass (4,313 metres high), the only way to Pangi tehsil from west, is also located in this region. The higher areas of the region remain covered with snow during most part of the year are barren. Nikora and Tal glaciers are located in the south-western part of the region. Some tributaries of Ravi River, namely, Tundah Nala and Budhil Nala also originate from this region. The Himalayan SubAlpine type of forests mainly of Fir and Birch grow in the region. However, the higher slopes are covered with grassy meadows.

The region has the geological structure of Jutogh group Vaikrita group/Central gneiss and Granites (unclassified). Udalfs soils are found in the northern and eastern parts of the region while southern part has Ochrepts Orthents type of soils.

\subsubsection{Dhauladhar Range}

This region is situated in the southern part of Chamba district covering some portion of Bhattiyat tehsil (except north-west portion), southern part of Chamba tehsil and Holi sub-tehsil and south-western tip of Bharmaur tehsil. It makes its boundaries with the Ravi Basin in the north-west; north and north-east, Punjab and Kangra district surround it from south-west, south and south-east, respectively.
Physiography of the region reveals that the Dhauladhar in Chamba district forms a mountain barrier with high peaks. Hathidhar is another important lower hill range which runs parallel to Dhauladhar, in its south. A narrow tract formed between Dhauladhar range and Hathidhar is plain and fertile. Talang glacier is also located in south-western part of the region. The region has an altitude varying between 1,188 metres and 4,692 metres above the mean sea level. In the lower part of the region, the climatic conditions are similar to Kangra district and Siwalik areas while in the higher portion, it is temperate. During winter, snowfall on the Dhauladhar range is very heavy. This range also receives very high rainfall during monsoon.

The region has formation of Granites (unclassified), Jutogh group/Vaikrita group/Central gneiss, Siwalik, Murree Series, Panjal Traps and Shimla group of geological structure. The region has Ochrepts-Orthents type of soils in the eastern part while Ochrepts-Orthents-Ustalfs types of soils are found in the western part of the region (Census report, 2001).

\subsection{Soils of Ravi River Basin in Himachal Pradesh:}

At the higher elevations the soil is well supplied with organic matters. Its extent is low at mid elevation and minimum in the low lying valleys. In Ravi River basin different types of soil are found. In sub-mountain and low hills, the soils are neutral in reaction and coarse in texture. In mid hill soils are acidic and coarse in texture. The high hills covering temperate dry zone, the soils are acidic in reaction, shallow in depth and sloppy. Whereas in high hills covering temperate wet zone, the soils are neutral and coarse in texture (Director of agriculture Chamba and Kangra). The typic udorthents and dystric eutrochrepts soils only available in Saluni and Chaurah areas of this basin. Typic-hapludolls soil is found in Chamba, Bhalai and Dalhousie tehsil areas of this basin in small portion of land. The dystricfluventic-eutrochrepts soil is only found in Dalhousie tehsil adjoining to Punjab State and in some portion of Bhattiyat areas of this basin. The lithic-udorthents and dystric-eutrochrepts types Soil are only found in Chamba and Chaurah tehsil areas of this basin (ICAR, Nagpur). The typic-udorthents soil is found in pirpanjal areas of Chamba, Bharmour Chaurah and Multhan tehsil and in some little bit in Saluni, Bhalai and Dalhousie tehsil areas of Dauladhar range of Ravi River basin. The typic-gryorthents soil is concentrated in Multhan, Bharmour, Chamba, Saluni and Chaurah tehsil areas adjoining to Lahaul and Spiti, Kullu, Pangi tehsil and Jammu and Kashmir State (Singh, R.B, 2014) (Fig. 2). 


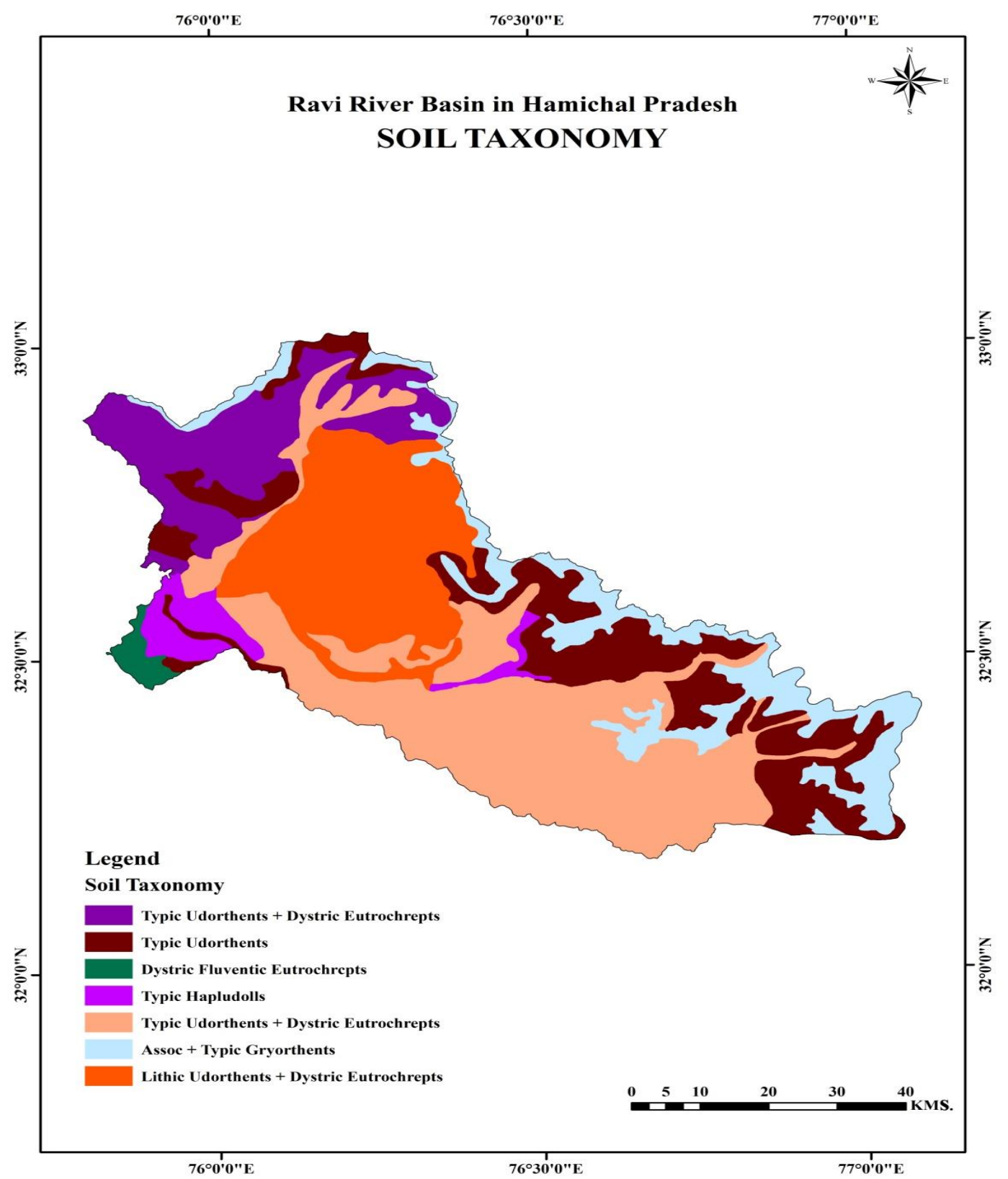

Source: Modified after Singh, R.B. (2014)

Figure 2

\subsection{Climate of Ravi River Basin in Himachal Pradesh}

As the Ravi River basin is wholly mountainous, with altitudes ranging from 559 meters to 5563 meters above mean sea level, a variety of climate is found from the semi-tropical to the semiarctic. In the lower part of Bhattiyat tehsil, the climatic conditions are similar to those of Kangra and the Shivalik area. The temperature begins to increase rapidly after the middle of April and this rise continues till the break of rains in July. In the Ravi valley the climatic conditions vary with altitude.In the lower portion of the valley from the capital downwards they are semi-tropical. The heat is there and the rainy season well marked, while winter is mild and the snowfall light.

In Bharmour, Holi and Bara Bhangal areas summer is exceedingly mild and pleasant. Owing to the scarce rainfall the percentage of humidity is always low. The winter is very severe and snowfall starts in October and continues till March and April. The district is having rainy season from middle of June to the middle of September and has vastness of the rainfall during this season. Snow may fall as early 


\section{Available online at www.ijrat.org}

as the beginning of October. The snowfall on the Dhauladhar and and Pirpanjal range is heavy and in severe winter it lasts from the early November to late March (Census report, 2001).

\subsection{Elevation of Ravi River Basin in H.P.}

The elevation of Ravi River basin in H.P varies from 559 meters to 5563 meters. The elevations of 1000 meter or below are found in Bhalai, Chamba, Bhattiyat and Dalhousie tehsil of Ravi River basin. The elevations between 1000 meters to 3000 meters are concentrated in all the tehsils of Ravi River's tributaries bed and low lying areas. It is found out from contour map the elevation between 3000 meters to 5000 meters are found in upper areas of Bharmour, Chamba, Holi and Chaurah tehsils and adjoining areas of Saluni to Jammu and Kashmir State and this class of elevation does not appear in Bhalai, Dalhousie and Bhattiyat tehsil of Ravi River basin in H.P. It is also found out from contour maps of Chamba and Kangra District of Himachal Pradesh that the elevation above the height of 5000 meters are only found in Multhan, Holi and Bharmour tehsil's adjoining areas of Lahaul and Spiti, Kangra and Kullu District (Figure 4).

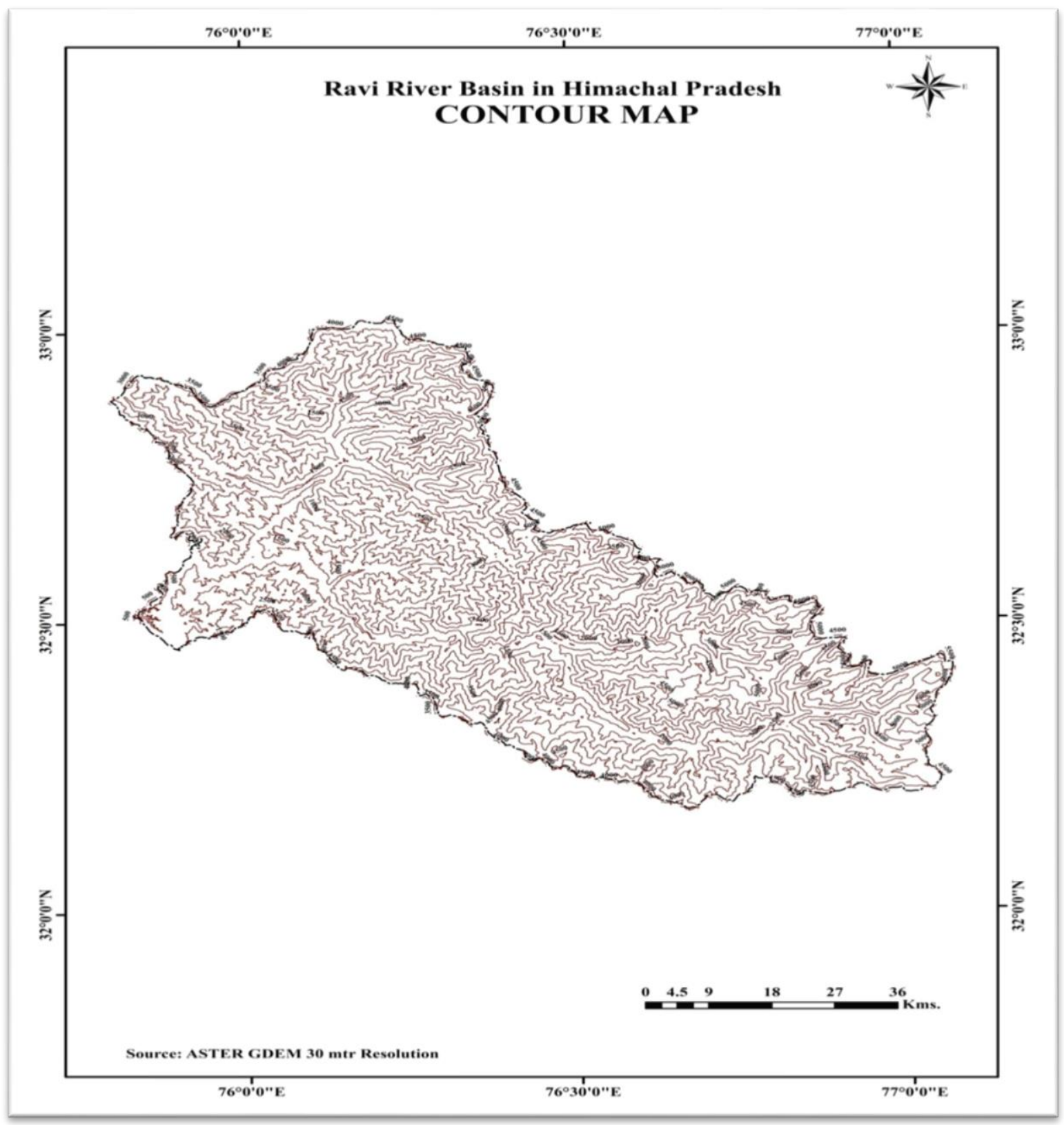

Figure 3 


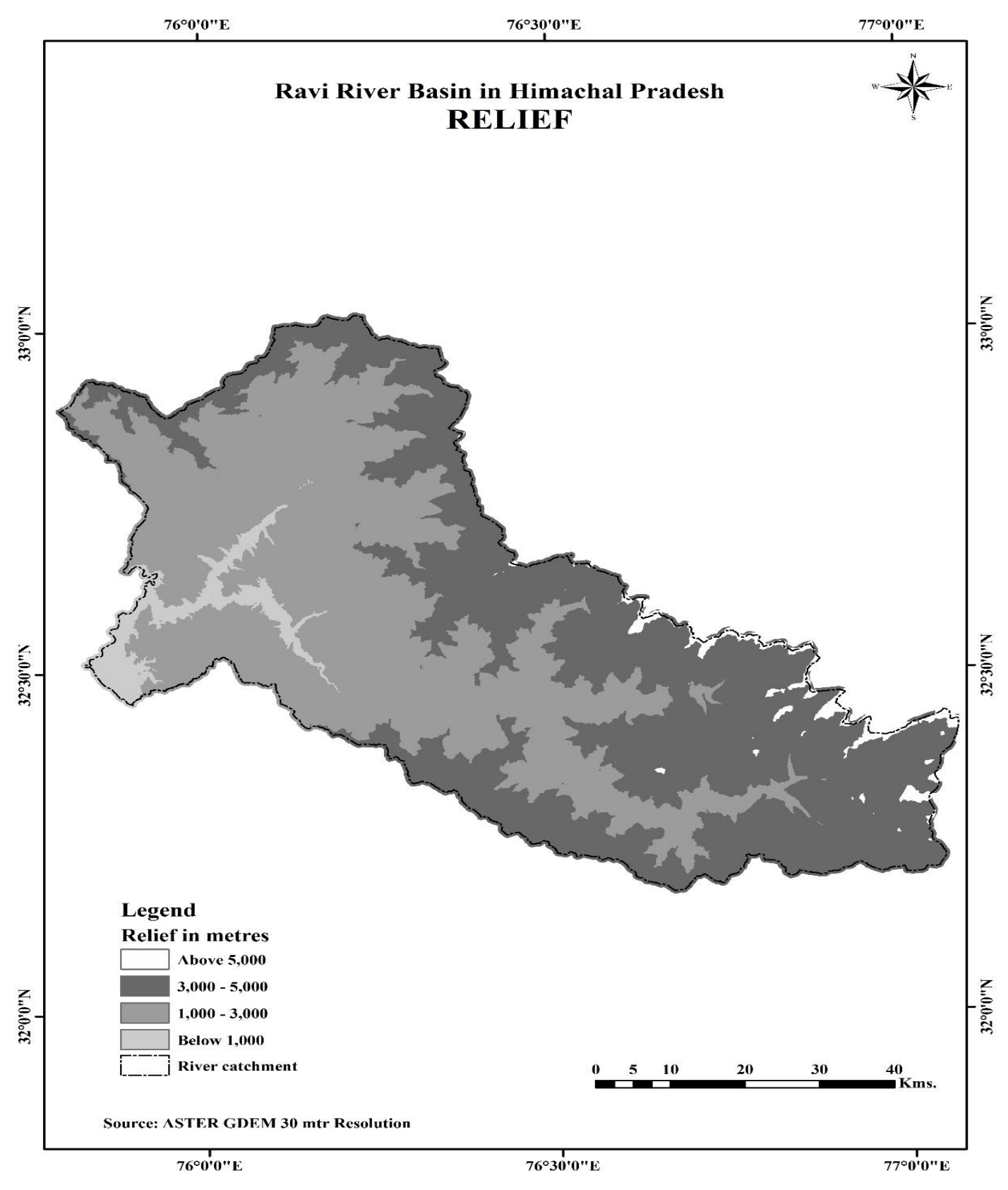

$4.8 \quad$ Figure 4 Pradesh

Slope defined as angular inclination of terrain between Mountain tops and Valley bottoms, resulting from combination of many causative factors like Geological structure, absolute and relative relief, Climate, Vegetation cover, drainage texture and frequency, dissection index etc. are significant morphometric attributes in the study of landforms of a drainage basin (Singh and Srivastava, 1975). The Slope of Ravi River basin in Himachal Pradesh categorizes may be further regrouped into five classes as follows: 1) $5^{\circ}$ gentle Slope, 2) Moderate Slope $5^{\circ}$ to $\left.10^{\circ}, 3\right)$ Moderately steep Slope $10^{\circ}$ to $\left.15^{\circ}, 4\right)$
Moderately steep Slope $15^{\circ}$ to $30^{\circ}$ and 5) above $30^{\circ}$ are steep Slope. The gentle slope areas of Ravi River basin in Himachal Pradesh are concentrated in Chamba tehsil's area near Ravi River catchment, Bhalai and Dalhousie tehsil areas of Ravi vicinity. In these areas the slope angle is less than $5^{\circ}$. The $5^{\circ}$ to $10^{\circ}$ moderate slope areas are concentrated in low lying areas of Bharmour, Holi and Chamba tehsil. The moderately steep slope areas where slope is $10^{\circ}$ to $15^{\circ}$ are concentrated in all the tehsil's of Ravi River basin in Himachal Pradesh. The steep slope areas are concentrated to almost the entire basin in Himachal Pradesh because the entire Ravi basin belongs to dissected topography areas (Figure 5). 


\section{Available online at www.ijrat.org}

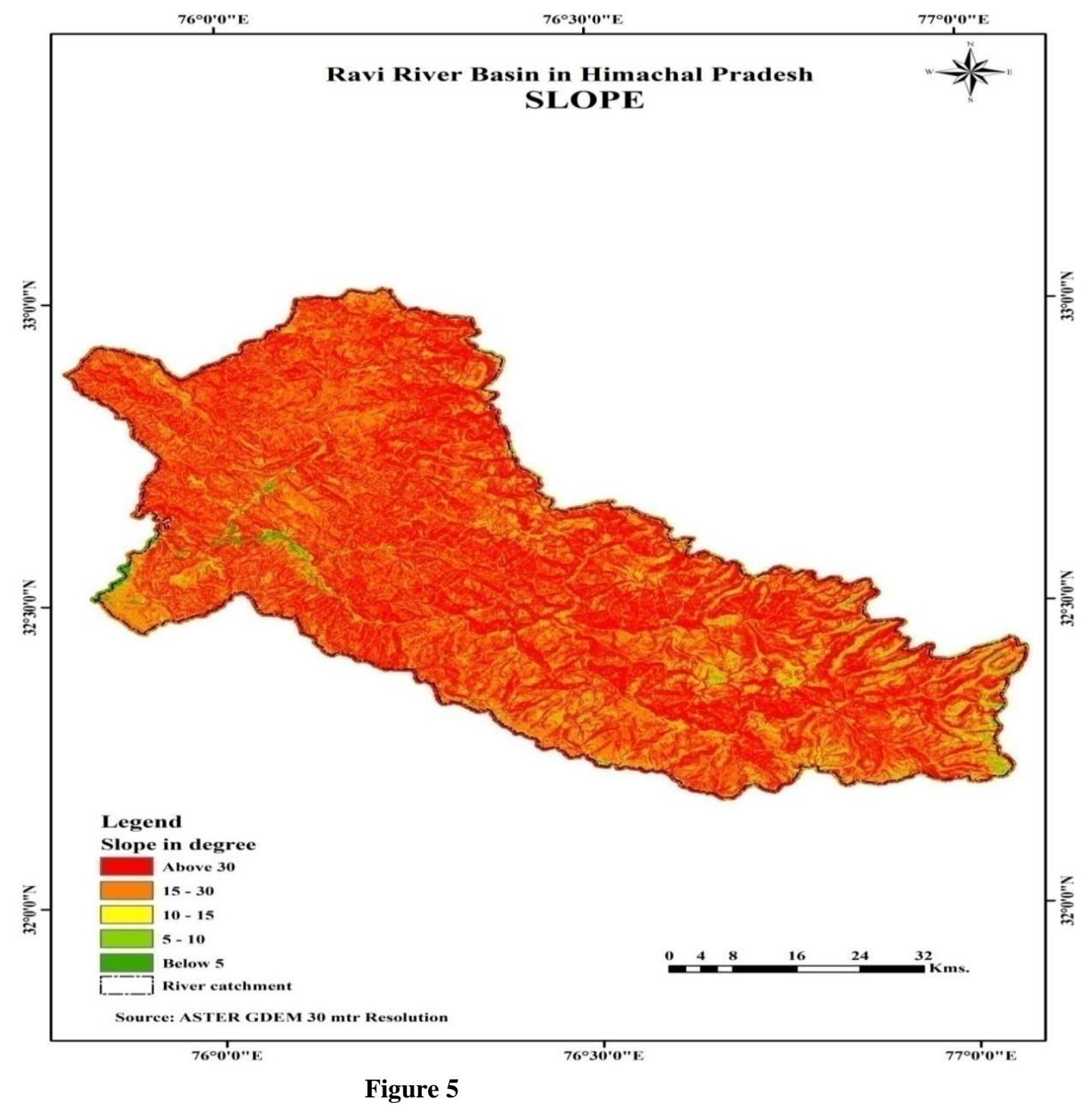

\subsection{Regional Geology of Ravi River Basin in} Himachal Pradesh

The Ravi Basin of Himachal Pradesh is located in lesser Himalaya and it is characterized by sharp crested ridges and deeply dissected valleys. The main drainage in this basin area is provided by the River Ravi which originates in Bara Bhangal area and its tributaries which are originate in Pirpanjal and Dhauladhar Ranges of Lesser Himalayas. The River initial reaches up to Khadamukh between TipriChamba and Raj Nagar Khas flows along the regional strike of rocks and cuts across the strike between Khadamukh and Tipri. The influence of lithology and structure is clearly evident from drainage by its semidendritic and rectangular pattern geologically the region exposes rocks ranging in age from early Proterozoic to Mesozoic. The rocks of this basin area are extensively covered by slope debris, fluvial terraces and fan of the deposits of Quaternary recent origin.
The area from the confluence of Siul River with the Ravi River south of Bhalai-Koti-PukhriMasrund-Kiani, between Chamba-Braur along the Saho Nalla and between Chamba-Gehra- Chatrari along Ravi River is underlain by the interstratified sequence of slate, phyllite, Schist, siltstone, quartzite of the Vaikrita Group. The conglomerate of the Manjir Formation is exposed south of Manjir, a little east of Masrund, between Baraur-Saho and east of the Saho and east of Balu nallah with Ravi River, north of Gehra. Further east Masrund, east of Saho and east of Balu nalla the area is underlain by carbonaceous slate, phyllite, Schistone quartzite, siltstone, limestone/magnesite of the Katarigali Formation. The basic volcanics (Panjal Formation) is exposed as linear belt east of Masrund and Saho and show closure upstream of Kiri nallah. Further east, the carbonaceous shale, state siltstone, phyllite, quartzite and limestone of the Salooni Formation are exposed and show closure upstream of Kiri nallah east of 


\section{Available online at www.ijrat.org}

Saho. The Kalhel Chhatri area is dominated by the limestone of kalhel Formation which show closure north of Saho around Shilla-Gharat area.Further east, the area is underlain by the rocks of Katarigali Formation. Then a big stretch of area extending from a little south of Mangla and Mehla along the higher reaches bordering Kangra District is underlain by granite gneiss and granite. Further west of Rajnagar towards Bhalai, these granites extend as narrow belt. The lithology of this formation is predominantly characterised by intersbedded grey to green malasilt stone, quartzite, slate, phyllite and greywake. In Sangned area, this formation is exposed in a series of low plunging anticlines and synclines with fold axes trending in NW-SE direction. The slate bears limonitic encrustations due to leaching of ferruginous matter. The schist in general consists of quartz, sericite, biotite and chlorite. Chlorite at places is developed as an altered product of biotite (Hydro Electricity Report, 2004).

The Saluni formation rocks are concentrated in large portion of entire basin excluding Bhattiyat areas, but it is found in Bharmour, Holi, Chamba and Multhan areas of this basin. Manjir formation rocks are available in some areas of basin in little portion excluding Bhalai, Dalhousie and Bhattiyat areas. The shiwalik formation rocks are only found in Dalhousie and Bhattiyat areas of this basin. The Mandi formation rocks are found in Saluni, Dalhousie and Bhalai areas of this basin. The Karol formation rocks are only found in Saluni and Chamba tehsil areas in very diminutive portion. The Dauladhar formation rocks are only found in Dalhousie, Chamba and Holi tehsil's high altitude areas of Dauladhar mountain range. The Zulughz formation rocks are only found in Chaurah, Saluni, Bhalai, Dalhousie, Chamba and Holi tehsil areas of this basin (Fig. 6).

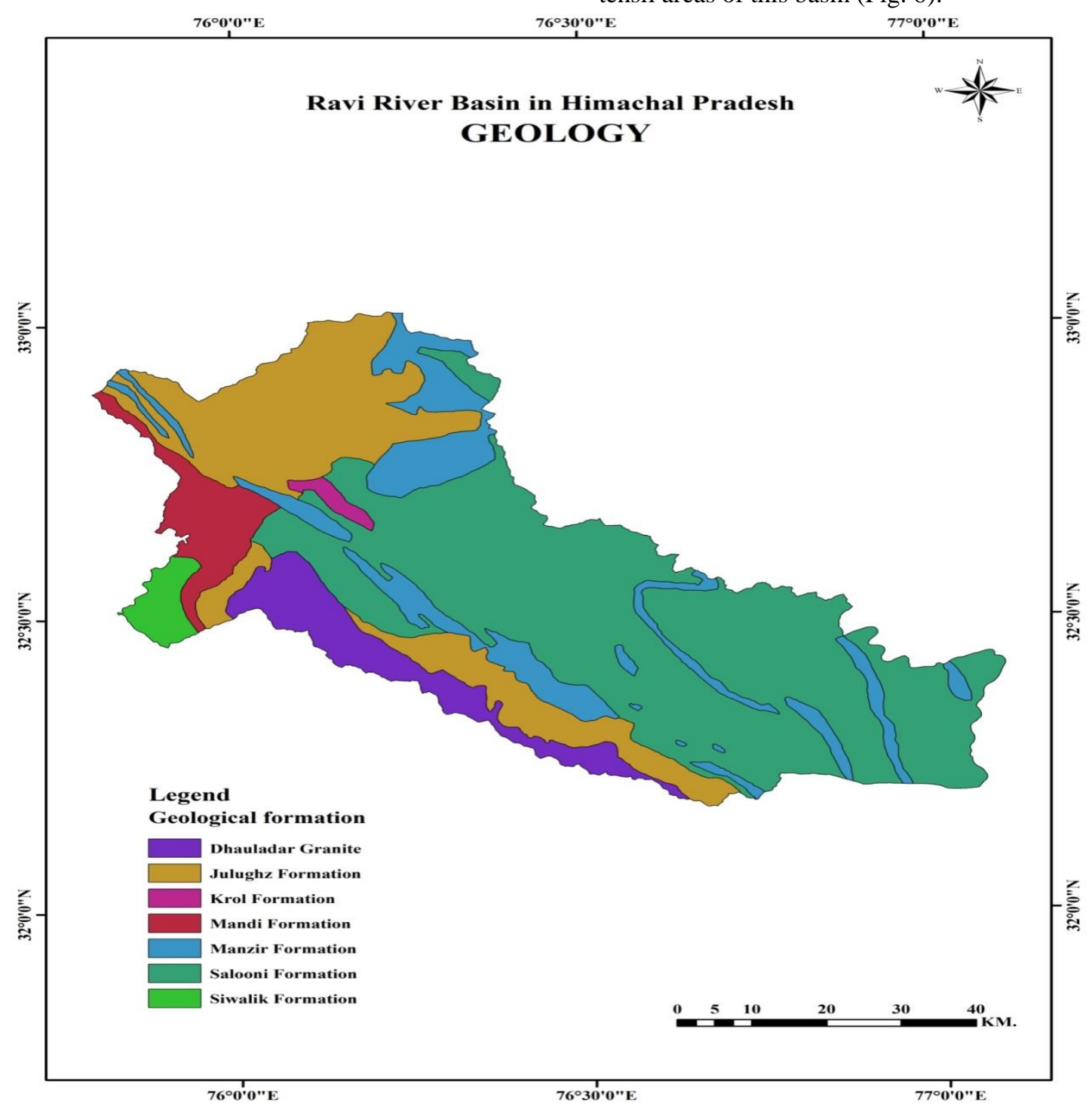

Source: Modified from central ground water board map.

Figure 6 


\section{CONCLUSION}

A geophysical background of Ravi River basin study are very useful to analyse and identify immense utility in drainage basin, elevation, watershed prioritization for soil and water conservation, flood Prediction and natural resources management. Application of Morphometric approach revealed that there are total 34293 streams grooved with each other from order 1st to 8th sprawled over $5451 \mathrm{~km} 2$ area of the basin in Himachal Pradesh. Detailed study of Ravi River basin gives a useful direction for surface runoff and helps for natural resource development. Bifurcation ratio indicates that the drainage has covered by impermeable sub surface and high mountainous relief. The study area shows that terrain is made up of mainly basaltic rock and exhibits dendritic and Herringbone drainage pattern is classified as highly sloping and high runoff zone which give rise to high drainage discharge. Lying mostly on both sides of the Pirpanjal and touching the Dauladhar on the southern fringe, the Ravi catchment area is rugged and covered with the spurs of the high ranges. The Dhauladhar range separating the basin of the Beas from that of the Ravi, the Pangi or Pirpanjal range dividing the Watershed between the Ravi and Chenab are the two well defined snowy ranges, constituting the main topographical features of the area. At the higher elevations of this basin the soil is well supplied with organic matters. Its extent is low at mid elevation areas but it is very less in the low lying valleys. In sub-mountain and low hills, the soils are neutral in reaction and coarse in texture. In mid hill soils are acidic and coarse in texture. The high hills covering temperate dry zone, the soils are acidic in reaction, shallow in depth and sloppy. Whereas in high hills covering temperate wet zone, the soils are neutral and coarse in texture. As the Ravi River basin is wholly mountainous, with altitudes ranging from 559 meters to 5563 meters above mean sea level, a variety of climate is found from the semi-tropical to the semi-arctic. The influence of lithology and structure is clearly evident from drainage by its semidenritic and rectangular pattern geologically the region exposes rocks ranging in age from early Proterozoic to Mesozoic. The rocks of this basin area are extensively covered by slope debris, fluvial terraces and fan of the deposits of Quaternary recent origin.

\section{REFERENCES}

[1] HydroElectricity Report. (2004), Himachal Pradesh, pp.47-48.

[2] Singh, S. (1997), Physical Geography, Prayag Pustak Bhawan, Allahabad, pp.226.

[3] Singh, S. (1997), Physical Geography, Prayag Pustak Bhawan, Allahabad, pp.226-227.
[4] Singh, S. (1997), Physical Geography, Prayag Pustak Bhawan, Allahabad, pp.230-231.

[5] Hydro Electricity Report. (2004), Himachal Pradesh, pp. 46-47.

[6] Balokhra, J.M. (2000), The Wonderland Himachal Pradesh, H.G. Publication, New Delhi, pp. 55 .

[7] Hydro Electricity Report,(2004), Himachal Pradesh, pp. 35-36.

[8] Singh, R.B. and Kumar, P. (2014), Geographic and Socio-Economic Realities of Himachal Pradesh, Northwestern Himalaya, Springer, Vol. viii, p. 16. 